\title{
RELATION OF THE "ANTI-STIFFNESS FACTOR" TO COLLAGEN DISEASE AND CALCINOSIS
}

\author{
BY \\ JOHN LANSBURY, LAWRENCE W. SMITH, ROSALIND WULZEN, \\ and WILLEM J. VAN WAGTENDONK \\ From the Departments of Medicine and Pathology, Temple University School of \\ Medicine, Philadelphia, Pa., U.S.A., and the Departments of Zoology and \\ Chemistry, Oregon State College, Corvallis, Ore., U.S.A.
}

\section{The Relation of the Anti-Stiffness Factor to Collagen Disease and Calcinosis}

The " anti-stiffness factor " is a fat-soluble vitamin which regulates phosphorus metabolism. The object of this communication is to report studies on the possible relations of the anti-stiffness factor to human disease. Since none of the work on the anti-stiffness factor has appeared in journals devoted to clinical matters, the essential experimental findings are briefly summarized below.

Sources and Nature of the Anti-Stiffness Factor.-The crude sources of the antistiffness factor are green vegetables, raw cream, unheated molasses, and raw sugarcane juice. The nature of the active principle is still unknown. Active fractions, however, are fat soluble. Reliable assay is difficult; Gouley found that methylvinyl-ketone had some anti-stiffness activity, but this has not been confirmed as the active principle. Oleson and others (1947), and Petering and others (1948), suggested ergostanyl acetate and alpha-ergostanyl acetate respectively as the active principle. Van Wagtendonk and Wulzen (1943) isolated a fat-soluble fraction from raw cream curative in doses of $0 \cdot 1 \mu \mathrm{g}$., and (1946) a crystalline substance from molasses and cane juice which was active in doses of $0.002 \mu \mathrm{g}$. Ross and others (1949) have recently presented evidence for the presence of a steroid compound in cane juice which exhibits anti-stiffness activity.

\section{Animals Lacking Anti-Stiffness Factor}

Smith and Elvove (1929) produced calcification in animals by a diet high in phosphorus and ergosterol, and Stephens and Barr (1933) did the same by a diet high in calcium, phosphorus, and acid. But the production of calcific deposits by a deficient diet dates from the work of Wulzen and Bahrs (1936); they reported that guinea-pigs maintained for months on a diet lacking in green vegetables developed general muscle stiffness and pain on movement of the carpal joints. As the condition progresses, the skeletal muscles atrophy, the animal becomes rigid in extension with flaring of the rib cage, and ultimately there are deposits of calcium salts between the muscle fibres, around the joints, and under the skin in the majority of the animals. These may break down and discharge calcium salts. Late manifestations include widespread deposits of calcium in and around blood vessels, and in parenchymal tissues such as the stomach and intestines. In some instances the skin is adherent to the underlying structures. In advanced cases there may be 
deafness, corneal flattening, alopecia, polydypsia, diarrhoea, and eventual death. Similar lesions have been induced in both omnivorous and carnivorous animals.

Pathology.-The muscles showed atrophy, necrosis, fragmentation, hyaline changes, and collagen necrosis with little cellular reaction and no fibrosis. A great deal of the collagen necrosis was located in and around blood vessels in the intestinal submucosa, in the intertubular spaces in the kidney, and in peri-articular tissues, and was frequently associated with calcific deposits. The joints themselves were not involved. Macrophages and giant cells were occasionally noted in the affected muscles. Patchy necrosis of liver cells with occasional calcification was observed. Varying degrees of atrophy of testicular tubules occurred.

Abnormal Physiology.-A macrocytic anaemia, eosinophilia, increased sedimentation rate, and reversal of the Albumin/Globulin ratio were observed. A variety of disturbances in body chemistry was noted by Van Wagtendonk and others (1943-49); most important among these, for our present purposes, are a decrease in hydrolysable phosphorus in liver and kidneys, and a lowering of creatine phosphate and of adenosine-phosphates in muscle.

It is believed that this deranged phosphorus metabolism leads to a higher level of non-diffusible calcium in the blood, probably in the form of a colloidal calcium phosphate complex (Van Wagtendonk and Freed, 1947), which, in chronically deficient animals, is deposited in the tissues as calcium phosphate and carbonate. Creatinuria does not occur.

Reversibility of Lesions.-All these abnormal changes can be prevented by the addition of fresh kale or raw cream to the deficient diet. Continued administration of a fat-soluble fraction from unpasteurized cream reversed the derangements in phosphorus and calcium metabolism, and large doses eventually caused resorption of the deposits of calcium and disappearance of the "clinical " manifestations of the deficiency syndrome. Thus it is evident that this dietary factor behaves as a fat-soluble vitamin and is concerned in the regulation of phosphorus and calcium metabolism. That the deficiency state is not due to lack of any of the known vitamins is shown by the studies of Van Wagtendonk (1944) who found that the syndrome develops despite the addition of optimal amounts of (1) thiamin-chloride riboflavin, pyridoxine-hydrochloride, calcium pantothenate, biotin, inositol, $p$-amino-benzoic acid, choline, and ascorbic acid; (2) carotene, viosterol, alphatocopherol, and 1.4 dimethyl naphthoquinone. (Cod-liver oil hastens the onset of the symptoms and aggravates them when present; Van Wagtendonk and Wulzen, 1943.)

\section{Application to Human Disease}

Since muscle stiffness is common to several rheumatic diseases, the possibility that lack of the anti-stiffness factor might play a role in these diseases seemed worthwhile investigating. Radiographs (Fig. 3) of a guinea-pig kept for 19 months on a diet lacking the anti-stiffness factor disclosed lesions typical of circumscribed calcinosis and stimulated us to collect and study a series of cases of this rare disease for comparison with the experimental lesions and for a therapeutic trial of the anti-stiffness factor. 


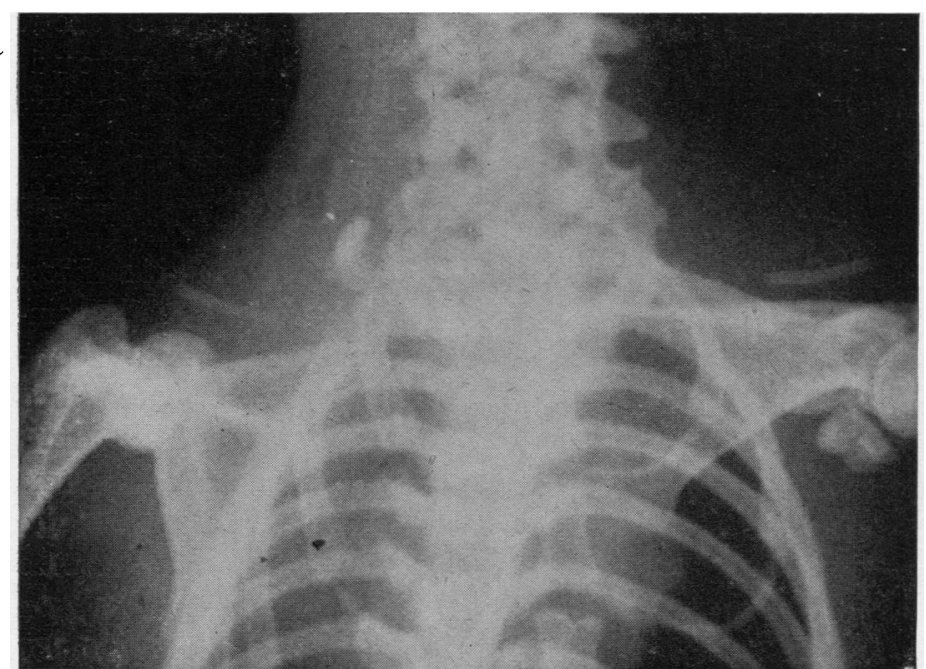

FIG. 1.-Early calcification deep in the neck in a guinea-pig after 7 months on a diet deficient in the anti-stiffness factor (cf. Fig. 2).

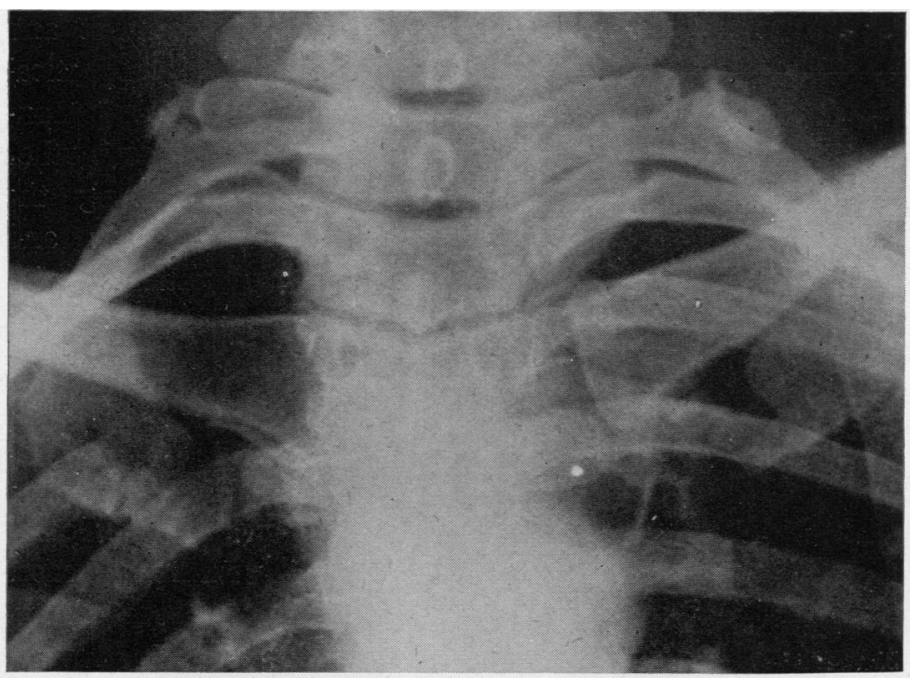

FIG. 2.-Early calcification deep in the neck of patient Mrs. M., 11 years after onset of scleroderma.

Durham (1928), Rothstein and Welt (1936), and Atkinson and Weber (1938).

Comparison of Experimental and Spontaneous Calcinosis.-In Figs 1 and 2, identical, small, circumscribed calcium deposits are seen to be situated deep in the root of the neck directly opposite the origin of the first rib, a not uncommon site for calcium deposition early in the course of scleroderma. Fig. 1 shows a guineapig deprived of the anti-stiffness factor for seven months. Fig. 2 shows a patient, Mrs. M., who had suffered from typical diffuse scleroderma for eleven years. This radiograph was taken in 1935 , at which time no other calcifications were 


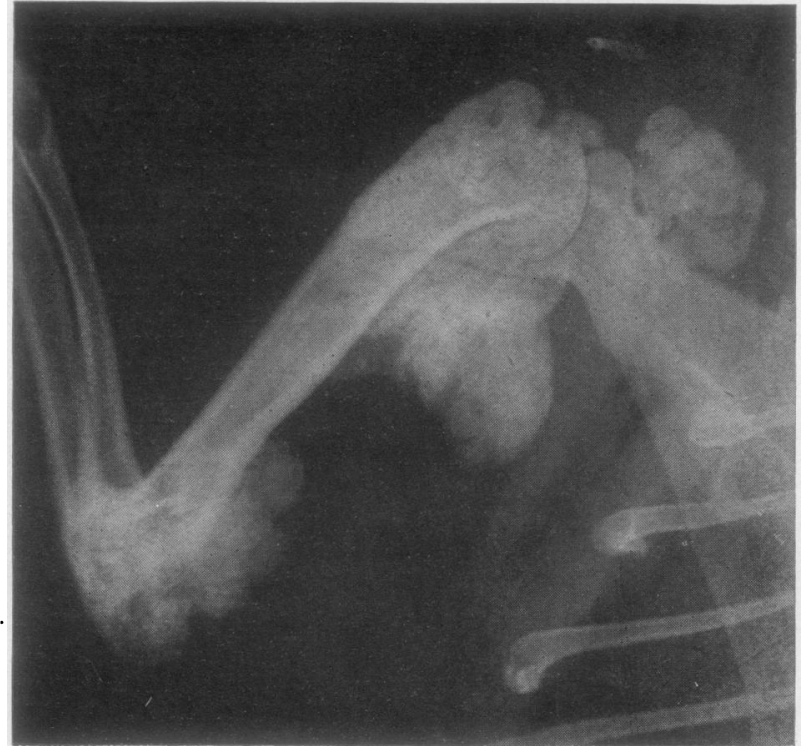

FIG. 3.- Shoulder of guinea-pig on diet lacking the anti-stiffness factor for 19 months (cf. Fig. 4).

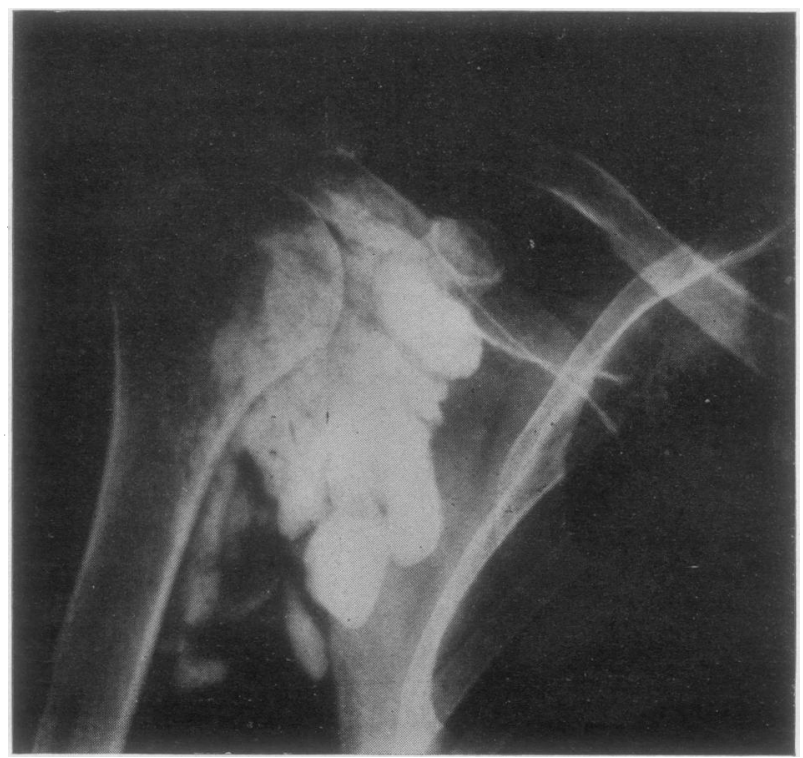

Fig. 4.-Shoulder of patient Mrs. M., taken 9 years after Fig. 2 , showing progress of circumscribed calcinosis similar to that of guinea-pig in Fig. 3.

detected. Fig. 3 shows circumscribed, cloudlike deposits of calcium round the shoulder joint of a guinea-pig kept for 19 months on a diet deficient in anti-stiffness factor and may be compared with Fig. 4, showing the circumscribed deposits which had developed in the same patient (Mrs. M.) in the 9-year interval since the first radiograph shown in Fig. 2. Many similar deposits were demonstrated near large joints in both the patient and the guinea-pig. Identical lesions have been demonstrated in numerous other guinea-pigs lacking the anti-stiffness factor and in many patients with long-standing scleroderma.

A search was now made for guinea-pigs showing a diffuse type of calcification for comparison with human cases of spontaneous interstitial calcinosis. Several such animals were found, and Fig. 5 clearly shows diffuse calcification in the subcutaneous tissues and muscles with general atrophy of these tissues.

There is complete absence of circumscribed calcifications near the joints or elsewhere. An almost identical picture is presented for comparison in Fig. 6. This is from a patient, Miss D., aged 23, whose record was supplied by Dr. George Farrar and Dr. D. A. Simpson of the Episcopal Hospital. This patient had had generalized swelling 
and redness of the skin after a respiratory infection four years before admission. The muscles were quickly involved and within one year skin and muscles were bound down to the underlying structures over wide areas of the body and hardened to the consistency of leather. There were widespread flexion deformities, emaciation, and

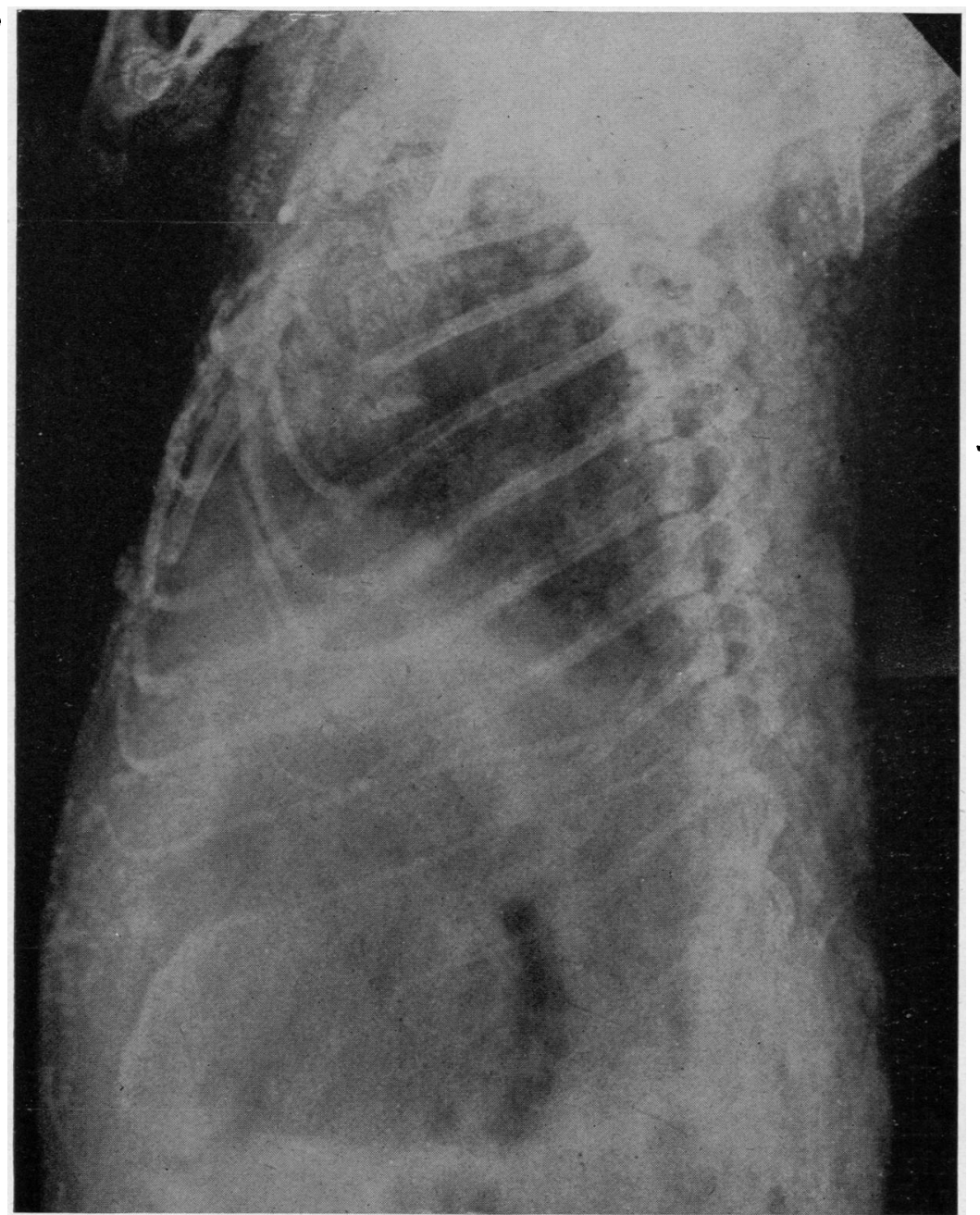

Fig. 5.-Guinea-pig on diet deficient in the anti-stiffness factor, showing interstitial calcification in the chest wall (cf. Fig. 6).

episodes of fever. Laboratory studies showed anaemia and elevated total serum proteins. No calcifications were noted a year prior to this study. A diagnosis of interstitial calcinosis complicating dermatomyositis was made. The patient had taken irradiated ergosterol for a few weeks before entering the hospital, but it is felt to be unlikely that the universal calcifications could have occurred in this short period of time. (Similar interstitial calcinosis is known to occur in the absence of this medication.) 


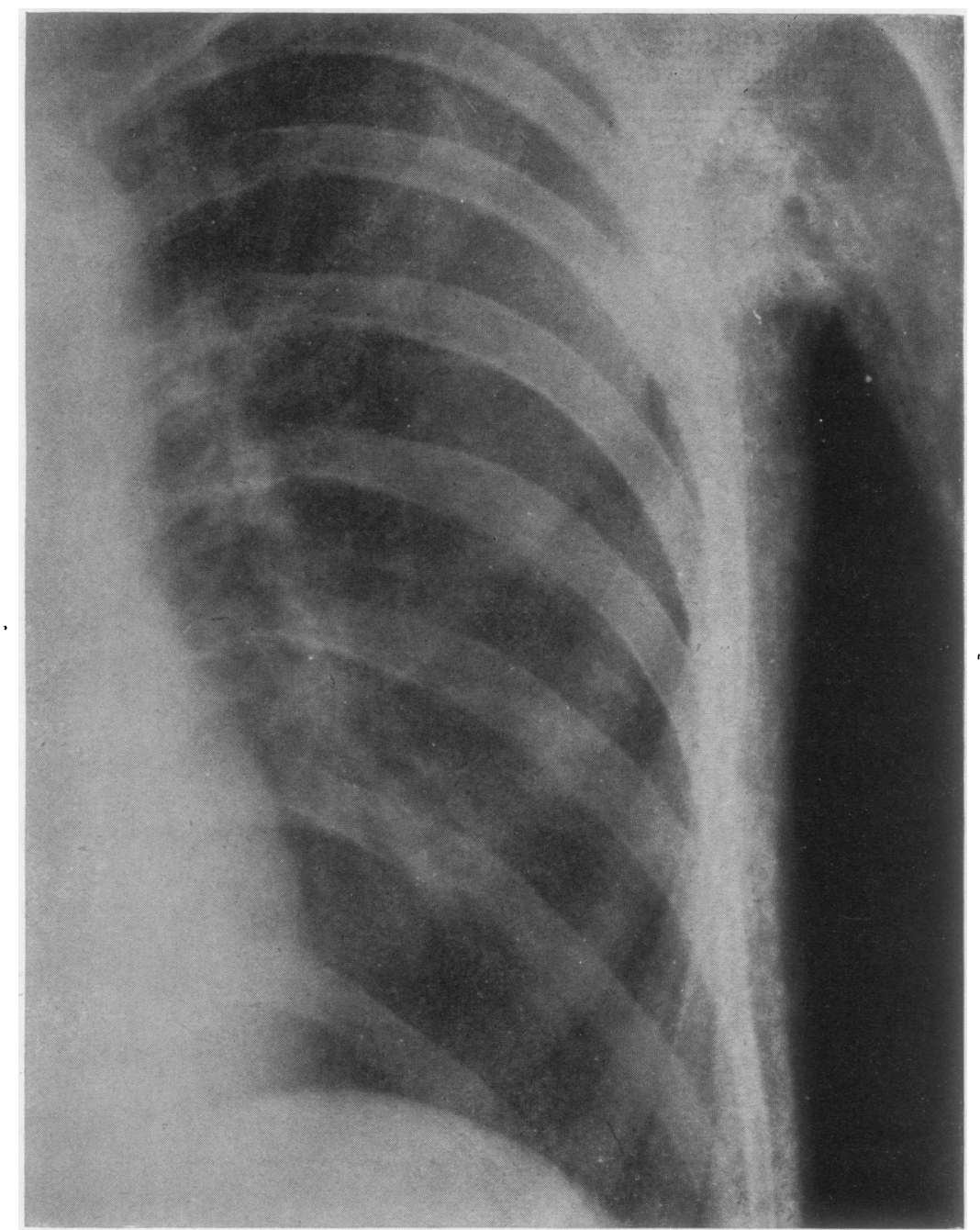

FIG. 6.-Thorax of patient Miss D., showing interstitial calcinosis in subcutaneous tissues.

Discussion.-The radiographs show an obvious and striking similarity between the calcific lesions induced by lack of the anti-stiffness factor in guinea-pigs and those of spontaneous human calcinosis. This is true for both the circumscribed and interstitial forms. It would seem to us most unlikely that both could be due to chance alone. We do not imply that human calcinosis is caused by lack of the anti-stiffness factor, but it seems very probable that some metabolic disturbance is common both to the experimentally induced and to the spontaneous lesions, and it is noteworthy that collagen necrosis is common to the whole group. In addition we have in the guinea-pigs other features frequently found in the collagen necrosis group of diseases (chronic fever without evidence for infection, anaemia, eosinophilia, increased sedimentation rates, and reversal of the Albumin/Globulin 
ratio). Of the two types, the interstitial calcinosis with muscle atrophy has more features in common with the guinea-pig lesions. The histopathology of the guinea-pig lesions is not identical either with that of scleroderma or of dermatomyositis (with or without calcinosis), although many similarities co-exist. Sclerodermatoid lesions have been reported in human cases of chronic malnutrition (McMillan, 1943), and rheumatic diseases are commonest in the low-income groups in which nutrition is apt to be poor.

Previous studies (Cornbleet and Struck, 1937; Leriche and Jung, 1935) have shown that scleroderma is frequently, if not always, associated with calcium retention even though it may not be demonstrable by $x$-ray. (Calcification is also found clinically in hyperparathyroidism, renal failure, Paget's disease, etc., but is not generally of the same degree or distribution as that found in calcinosis and would not, therefore, seem related to the present study.)

It is important to evaluate the possible role of vitamin $\mathrm{D}$ in the production of the calcifications in both patients and animals since hypervitaminosis $D$ can cause circumscribed calcifications quite similar to those observed in calcinosis (Freeman and others, 1946). Regarding the patients, the calcification caused by hypervitaminosis $\mathrm{D}$ tends to disappear after withdrawal of the drug, whereas, in calcinosis, the calcifications are regrettably permanent. Both circumscribed and interstitial calcinosis were described before the present era of high vitamin D dosage, made possible by the ergosterols. As reported in the literature, calcinosis characteristically occurs in the absence of vitamin D medication. It is, of course, possible that the administration of vitamin $\mathrm{D}$ might increase the tendency to calcification, since it aggravated the symptoms in the animals.

In the guinea-pigs the lesions developed on diets containing only physiologic amounts of cod-liver oil or ergosterol, but did not develop if the anti-stiffness factor was added to the same diets. Long-continued administration of the antistiffness factor caused the calcium deposits to disappear in some animals. The lesions were not due to the high calcium and phosphorus intake occasioned by a skimmed-milk-powder diet, since they did not develop when the anti-stiffness factor was added to the same diet.

\section{Clinical Trial of the Anti-Stiffness Factor}

The anti-stiffness factor, as present in raw cream, unheated molasses, and various concentrates, ${ }^{*}$ was administered to a small series of cases of rheumatoid arthritis and of primary fibrositis with no subjective or objective benefit. Because of the difficulty of assaying these various sources for their actual anti-stiffness potency, we do not feel sure that adequate amounts were actually administered.

A series of ten cases of scleroderma (some with, and some without, calcinosis), was collected and treated with various source materials and concentrates of the anti-stiffness factor for periods ranging from two months to two years. The disease had been present for periods ranging from two months to 35 years before treatment was instituted. Three of the cases showed clinical evidence for avitaminosis B:

* Supplied by Eli Lilly and Co. 


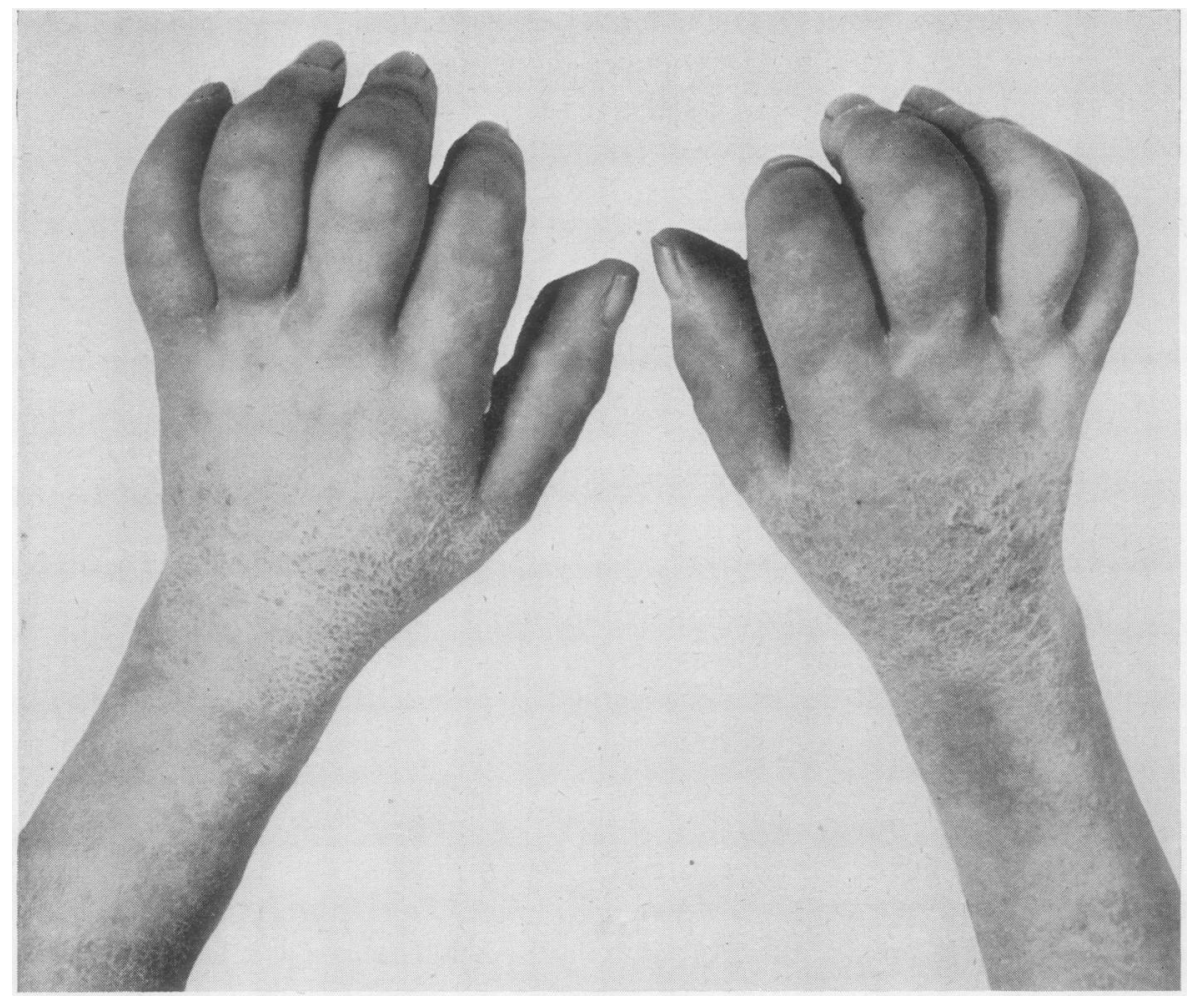

Fig. 7.-Hands of patient Mrs. A., aged 66, with scleroderma of 1 year's duration.

atrophy of the tongue, diarrhoea with vitiligo, and corneal vascularization respectively. In one case there was a definite history of malnutrition and inadequate vitamin intake.

In evaluating any treatment of scleroderma one should bear in mind that no improvement can be expected in those areas where the normal skin structures have been replaced by fibrous tissue. Any favourable effect would be confined to the oedematous and inflammatory areas of the skin where the disease is in its active phase. Also, it must be remembered that it is exceedingly difficult to evaluate objectively anything less than a major improvement.

Four of the ten cases of scleroderma exhibited calcinosis varying from a few spicules in the skin as shown by $x$-ray to massive deposits near many joints. Treatment with the anti-stiffness factor over periods of six months to two years in these cases failed to produce the slightest change in the calcium deposits. The negativity of these results is heightened by previous reports of successful removal or amelioration of calcinosis by a ketogenic diet, by ammonium chloride, and by low calcium diets. In five of the ten cases no change in the scleroderma beyond the normal variations of the disease could be determined. The average duration of treatment was seven months. One patient became pregnant during the observation period. Her scleroderma was not improved. 


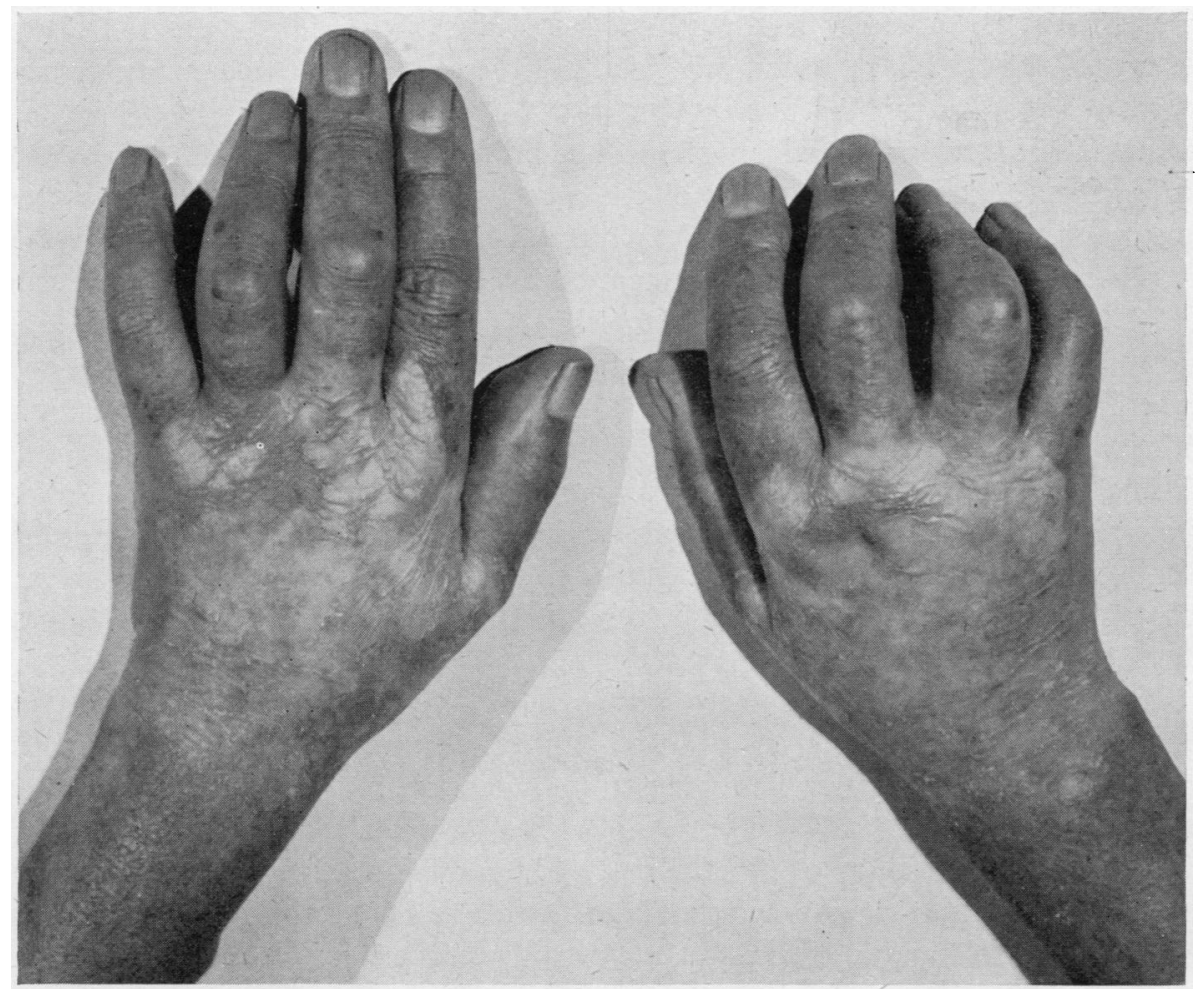

FIG. 8. - Change in hands of patient Mrs. A. after 8 weeks' treatment with a concentrate of the anti-stiffness vitamin (cf. Fig. 7).

In the remaining five cases, improvement occurred during treatment which we consider to be greater than could be explained by the natural fluctuations in the disease. In two of these there was a small but appreciable reduction of flexion deformities in the fingers, and in three others there was an approximately 50 per cent. reduction in the degree of swelling of the skin. This improvement was maintained, but levelled off and did not continue to the point of resolution. Figs 7 and 8 illustrate the most successful case. This patient, aged 66, had known diabetes of 13 years' duration. One year prior to our examination she developed stiffness in the flexors of the wrists and ankles, and thickening and tightness of the skin of all extremities. The hands were as in Fig. 7. The skin of the arms and legs was bound down, and over the dorsum of the hands and feet was macerated and fissured. This is not commonly a feature of scleroderma, but the referring dermatologist and the subsequent course of the disease confirmed the diagnosis as scleroderma.

The patient was given unheated cane molasses daily for several months with little or no benefit. After six months' use of $250 \mathrm{ml}$. of raw cream daily there was a questionable reduction in swelling. The treatment was then changed to an antistiffness concentrate, and within eight weeks there occurred the striking improvement shown in Fig. 8, which was maintained for six months with gradual healing 
of the fissures. At this time peculiar maculopapular lesions appeared above the knees. We were in doubt whether these lesions represented a progression of existing disease or were due to the large doses of the concentrate which had produced a red, maculopapular rash in some other cases. At this point treatment with anti-stiffness concentrate was discontinued and an oral bismuth preparation substituted. The lesions continued to regress, but very gradually. Three years after discontinuing anti-stiffness treatment the hands were essentially the same as in Fig. 8, except that the maceration of the skin had almost entirely cleared up, and the swelling of the skin of the forearms and legs had further receded leaving a brown atrophic skin partly bound down to the subadjacent structures, together with minor stiffness of the muscles, continued slight flexion deformities of some fingers, and minimal shortening of the plantar flexors of the feet.

In reviewing the whole course of this case, we see an improvement continuing over a period of over four years, but about 75 per cent. of the improvement occurred over a period of eight weeks coincident with exhibition of an anti-stiffness concentrate.

Reviewing these clinical data we may say that we have observed no objective benefit from administration of the anti-stiffness factor in rheumatoid arthritis, primary fibrositis, or calcinosis. Slight to moderate improvement occurred in four of the ten cases of scleroderma, and striking benefit occurred in one case of rather atypical scleroderma. On the bases of these findings we can state, without reservation, that the anti-stiffness factor, as available at the time of these studies, has no justifiable place in the treatment of scleroderma, dermatomyositis, or calcinosis. However, rather against our clinical feeling in the matter, a careful appraisal of the treated cases forces a conclusion that the anti-stiffness factor did cause a feeble amelioration in about half the cases of scleroderma. This would seem to reinforce the impression gained by us from comparison of the human and animal lesions that some common factor is at work in the production of both the spontaneous and experimental lesions, although this factor need not be the primary cause of either state. It is possible, for instance, that an increased concentration of colloidal calcium phosphate in the blood is the common denominator in the production of the calcinosis. It would seem that further clarification of the role of the anti-stiffness factor in human disease must await the full chemical identification of the active principle. The similarities of the lesions induced by lack of the anti-stiffness factor to the general picture of collagen disease and calcinosis seem sufficient to justify continued interest in this field. The anti-stiffness factor is not at present available for experimental or clinical use.

\section{Summary}

The anti-stiffness factor is a fat-soluble vitamin concerned with the regulation of phosphorus and calcium metabolism. Animals deprived of it develop a syndrome characterized by muscular degeneration and stiffness, calcinosis, both interstitial and circumscribed, and the general features of the collagen necrosis diseases (fever without infection, anaemia, increased sedimentation rate, eosinophilia, and reversal 
of the Albumin/Globulin ratio) as well as the histologic lesions of collagen necrosis. The anti-stiffness factor prevents the onset of these lesions and in the not too far advanced phases reverses them, including the calcinosis.

Treatment of ten cases of scleroderma, four with co-existing calcinosis, with sources and concentrates of the anti-stiffness factor indicates only a feeble beneficial effect on scleroderma and none at all on calcinosis. It was less effective than older treatments still in vogue.

The syndrome has, however, a number of features (clinical, pathologic, and radiographic) in common with calcinosis, dermatomyositis, and scleroderma, but it has also some differences, such as reversibility of the calcinosis in the experimental animals, a tendency to hyperextension deformity, and extreme lowering of the serum albumin. Species variation and the rigorous experimental conditions might explain some of these differences.

\section{Conclusion}

The experimental production of a collagen necrosis disease with calcinosis by means of a deficiency diet is of interest to the rheumatologist, and suggests the possibility of a nutritional factor in the pathogenesis of some of the collagen diseases. No claim is made that lack of the anti-stiffness factor is the primary cause of the scleroderma group of diseases, or that the increase of it in diet is effective in the treatment of these diseases.

\section{REFERENCES}

Atkinson, F. R. B., and Weber, F. Parkes (1938). Brit. J. Derm. Syph., 50, 267.

Bauer, W., Marble, A., and Bennett, G. A. (1931). Amer. J. med. Sci., 182, 237.

Cornbleet, T., and Struck, H. C. (1937). Arch. Derm. Syph., Chicago, 351, 188.

Craig, J., and Lyall, A. (1931). Brit. J. Child. Dis., 28, 29.

Durham, R. H. (1928). Arch. int. Med., 42, 467.

Freeman, S., Rhoads, P. S., and Yeager, L. B. (1946). J. Amer. med. Ass., $130,197$.

Kennedy, R. L. J. (1932). Proc. Mayo Clin., 7, 329.

Leriche, R., and Jung, A. (1935). Bull. Soc. franç. Derm. Syph., 42, 885.

McMillan, R. B. (1943). Brit. med. J., 2, 229.

Oleson, J. J., Van Donk, E. C., Bernstein, S., Dorfman, L., and Subbarow, Y. (1947). J. biol. Chem., 171, 1 .

Petering, H. G., Stubberfield, L., and Delor, R. A. (1948). Arch. Biochem., 18, 487.

Ross, L. E., Van Wagtendonk, W. J., and Wulzen, R. (1949). Proc. Soc. exper. Biol. Med., 71, 281. Rothstein, J. L., and Welt, S. (1936). Amer. J. Dis. Child., 52, 368.

Smith, M. T., and Elvove, E. (1929). Pub. Health Rep., 44, 1245.

Stephens, D. J., and Barr, D. P. (1933). Proc. Soc. exper. Biol. Med., 30, 920.

Van Wagtendonk, W. J., and Wulzen, R. (1943). Arch. Biochem., 1, 3.

-, Schocken, V., and Wulzen, R. (1944). Ibid., 3, 305.

— (1944). J. biol. Chem., 155, 337.

—, Rathkey, A. S., and Ballou, C. E. (1945). Arch. Biochem., 5, 329.

- Freed, A. M., and Ballou, C. E. (1945). Ibid., 5, 329.

$\longrightarrow$, and Zill, L. P. (1945). J. biol Chem., 159, 247.

$\longrightarrow$, and Freed, A. M. (1947). Ibid., 167, 225.

Wulzen, R., and Bahrs, A. M. (1936). Physiol. Zool., 9, 508.

\section{Le "Facteur d'Anti-Rigidité " par Rapport à la Maladie Collagène et la Calcinose \\ RÉSUMÉ ET CONCLUSIONS}

Le " facteur d'anti-rigidité " est une vitamine lipo-soluble qui joue un rôle dans la régulation du métabolisme du phosphore et du calcium. Les animaux qui en sont privés développent un syndrome caractérisé par dégénérescence musculaire et par rigidité, par calcinose aussi bien interstitielle que circonscrite, par des caractères généraux des maladies collagènes nécrotiques (fièvre 
sans infection, anémie, sédimentation globulaire augmentée, éosinophilie et inversion du rapport albumine/globuline) ainsi que par lésions histologiques de nécrose collagène. Le "facteur d'antirigidité "empêche l'apparition de ces lésions et si le processus n'est pas trop avancé, il est capable de le renverser, y compris la calcinose.

Le traitement de dix cas de sclérodermie, dont quatre avec la co-existence de calcinose, au moyen des sources et des extraits du "facteur d'anti-rigidité " ne donna qu'un résultat favorable très faible dans la sclérodermie et nul dans la calcinose. Il fut moins effectif que les traitements plus anciens encore en vogue.

Ce syndrome, tout en présentant un certain nombre de traits (cliniques, pathologiques et radiographiques) communs avec la calcinose, dermatomyosite et sclérodermie, montre également certaines différences, telles que la reversibilité de la calcinose chez les animaux expérimentaux, une tendance à la déformité en hyperextension et une diminution extrême de l'albumine sérique. Des variations d'espèce et des conditions expérimentales rigoureuses pourraient expliques certaines différences.

La création expérimentale de la maladie nécrotique collagène avec calcinose par carence alimentaire intéresse le rhumatologue et suggère la possibilité d'intervention d'un facteur alimentaire dans la pathogénèse de certaines maladies collagènes. On n'avance pas que la carence du " facteur d'anti-rigidité " soit la cause primaire des maladies du groupe sclérodermique ou que son augmentation dans la nourriture serait efficace dans le traitement de ces maladies.

\section{El “Factor de Anti-Rigidez" con Relación a la Enfermedad \\ Colágena y a la Calcinosis \\ RESUMEN Y CONCLUSIONES}

El " factor de anti-rigidez" es una vitamina lipo-soluble que desempeña un papel en la regulación del metabolismo del fósforo y del calcio. Animales privados de él desarrollan un síndrome caracterizado por degeneración muscular y por rigidez, por calcinosis tanto intersticial como circonscrita, por carácteres generales de enfermedades colágenas necróticas (fievre sin infección, anemia, sedimentación globular aumentada, eosinofilia e inversión de la razón albumina/globulina) así como por lesiones histológicas de necrosis colágena. El " factor de anti-rigidez" impide la aparición de estas lesiones y si el curso no está demasiado adelantado, lo puede invertir, aunque hubiese calcinosis.

El tratamiento de diez casos de esclerodermia, cuatro de ellos con calcinosis coexistente, con fuentes y concentrados del "factor de anti-rigidez", dió tan solo un pequeño resultado favorable en la esclerodermia y ninguno en la calcinosis. Fué menos eficaz que tratamientos más antiguos todavía en boga.

Este síndrome tiene, sin embargo, ciertos rasgos (clínicos, patológicos y radiográficos) comunes con calcinosis, dermatomiositis y esclerodermia, pero muestra también ciertas diferencias, como la reversibilidad de la calcinosis en los animales experimentales, tendencia a la deformación en hiperextensión y diminución excesiva de la albumina del suero. Variaciones de las especies y condiciones experimentales rigurosas podrían explicar algunas de estas diferencias.

La creación experimental de la enfermedad necrótica colágena con calcinosis por deficiencia alimenticia interesa al reumatólogo y sugiere la posibilidad de intervención de un factor alimenticio en la patogenesis de ciertas enfermedades colágenas. No se pretende aquí que la carencia del "factor de anti-rigidez" sea la causa primaria de las enfermedades del grupo esclerodérmico o que su aumento en la alimentación sería eficaz en el tratamiento de estas enfermedades. 